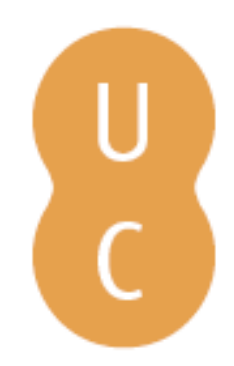

\title{
pompalina
}

\section{Los hijos de la fortuna de Calderón, celebración dramática (y musical) de las Etiópicas}

\author{
Autor(es): $\quad$ Salgado, Ofelia \\ Publicado por: Centro de Estudos Clássicos e Humanísticos da Universidade de \\ URL \\ persistente: \\ DOI: \\ Coimbra; Imprensa da Universidade de Coimbra \\ Accessed : $\quad$ 26-Apr-2023 07:27:48
}

A navegação consulta e descarregamento dos títulos inseridos nas Bibliotecas Digitais UC Digitalis, UC Pombalina e UC Impactum, pressupõem a aceitação plena e sem reservas dos Termos e Condições de Uso destas Bibliotecas Digitais, disponíveis em https://digitalis.uc.pt/pt-pt/termos.

Conforme exposto nos referidos Termos e Condições de Uso, o descarregamento de títulos de acesso restrito requer uma licença válida de autorização devendo o utilizador aceder ao(s) documento(s) a partir de um endereço de IP da instituição detentora da supramencionada licença.

Ao utilizador é apenas permitido o descarregamento para uso pessoal, pelo que o emprego do(s) título(s) descarregado(s) para outro fim, designadamente comercial, carece de autorização do respetivo autor ou editor da obra.

Na medida em que todas as obras da UC Digitalis se encontram protegidas pelo Código do Direito de Autor e Direitos Conexos e demais legislação aplicável, toda a cópia, parcial ou total, deste documento, nos casos em que é legalmente admitida, deverá conter ou fazer-se acompanhar por este aviso.

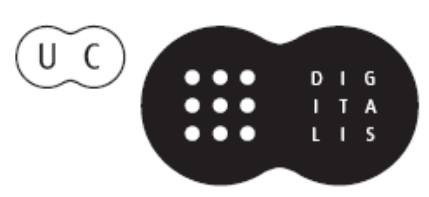




\section{De ayer a hoy}

\section{Influencias clásicas en la literatura}

\section{Aurora López, Andrés Pociña, Maria de Fátima Silva (coords.)}




\section{Los hijos de la fortuna de Calderón, celebración DRAMÁTICA (Y MUSICAL) DE LAS ETIÓPICAS}

Ofelia Salgado

Cambridge - Inglaterra

Los hijos de la Fortuna. Teágenes y Cariclea de Calderón de la Barca constituyó la más célebre adaptación a la escena de las Etiópicas, novela griega de amor y aventuras atribuida a Heliodoro de Emesa, y su publicación, en la Parte tercera de comedias de 1664, llevó a su cumbre la fama de esa "épica en prosa" antigua, después de más de un siglo de intensa difusión de la obra en España. Este drama corresponde a la segunda época de la producción de Calderón, de un teatro de espectáculo, en que el dramaturgo se interesa por temas fantásticos y novelescos, según A. Valbuena Briones. En las letras españolas había sido precedida por la comedia Teágenes y Cariclea de Juan Pérez de Montalván (1638) y antes, por imitaciones novelísticas, como El peregrino en su patria de Lope de Vega (1604) y la obra póstuma Los trabajos de Persiles y Sigismunda. Historia setentrional de Miguel de Cervantes (1617). Por sobre todo, cabe destacar que la adaptación a la escena de Calderón devuelve en cierta forma las Etiópicas a su género original y a sus fuentes prístinas de inspiración en la tragedia griega, en particular el Hipólito de Eurípides.

Los hijos de la Fortuna. Teágenes y Cariclea de Pedro Calderón de la Barca constituyó la más célebre adaptación a la escena de las Etiópicas, novela griega de amor y aventuras atribuida a Heliodoro de Émesa, y su publicación, en la Parte tercera de comedias de 1664, llevó a su cumbre la fama de esa "épica en prosa” antigua, después de más de un siglo de intensa difusión de esa obra en España. Este drama corresponde a la segunda época de la producción de Calderón, de un teatro de espectáculo, en que el dramaturgo se interesa por temas fantásticos y novelescos, según A. Valbuena Briones (1969: 2.1223). En las letras españolas había sido precedida por la comedia "Teágenes y Cariclea” de Juan Pérez de Montalván (1638) y antes, por imitaciones novelísticas, como El peregrino en su patria de Lope de Vega (1604) y la obra póstuma Los trabajos de Persiles y Sigismunda. Historia setentrional de Miguel de Cervantes (1617). Por sobre todo, cabe destacar que la adaptación a la escena de Calderón devuelve en cierta forma las Etiópicas a su género original y a sus fuentes prístinas de inspiración en la tragedia griega, en particular el Hipólito de Eurípides.

En su extensa producción dramática, Pedro Calderón de la Barca (1600-1681) no descuida los temas mitológicos clásicos y acude incluso a la novela antigua para proveerse de asuntos fantásticos o novelescos en su afán de 
crear un teatro de espectáculo. En esta búsqueda, correspondiente a la segunda parte de su producción, no vacila en alimentar su vena creativa en las narrativas épicas de la Antigüedad, como las Etiópicas, de amor y aventuras, la alegoría de las Metamorfosis o El asno de oro de Apuleyo ("Psiquis y Cupido", 1640), o inclusive en una novela en clave inspirada en la primera de las mencionadas, la Argenis del escocés Juan Barclayo (“Argenis y Poliarco”, 1637). Nos concentraremos aquí en su recreación dramática de las Etiópicas, por constituir ésta la culminación de más de un siglo de difusión, intensa lectura e imitación, tanto en prosa como en puestas en escena, de esa obra de ficción que disfrutó de tan "singular acogida en el Renacimiento"1.

En tanto que Valbuena Briones resalta en Los bijos de la Fortuna, Teágenes y Cariclea de Calderón "la habilidad técnica del dramaturgo español al adaptarla", ya que "retiene lo importante del argumento y permanecen los personajes principales, sin mermar el encanto de la peripecia ni el exotismo que caracterizan al texto primitivo"3, Francisco López Estrada sostiene que, comparada con la adaptación a la escena del doctor Juan Pérez de Montalván, publicada en el Segundo tomo de las comedias en 1638, "la obra de Calderón es, a todas luces, inferior a la de Montalván. Mientras éste tuvo buen cuidado de limitar y ordenar los sucesos, Calderón los amontona sin apenas sentido de continuidad, y propende a la comedia de gran espectáculo, con artificios escénicos, cantos corales, descuidando la hechura dramática"4. De lo que ese estudioso no se da cuenta es de que es justamente ese material lo más interesante de esa obra. Cabe recordar al respecto la influencia en Calderón de la Camerata florentina, que, integrada por los músicos Vincenzo Galilei, Jacopo Peri, Giulio Caccini y el poeta Ottavio Rinuccini, creó entre 1573 y 1587 el género operístico ${ }^{5}$, del cual ese dramaturgo proporcionará el primer gran ejemplo en España con su "El golfo de las sirenas", publicado en la Parte cuarta de las comedias, Madrid, $1672^{6}$. Calderón es, en efecto, un libretista, el primer gran libretista del drama musical italianizante en la península ${ }^{7}$. López Estrada no deja de señalar, sin embargo, que "ambas obras, la de Montalván y la de Calderón, de escaso valor literario, son un índice de la popularidad del libro de Heliodoro en este tiempo" ${ }^{\prime}$, es decir, a mediados del siglo XVII, entre 1638 y 1664 .

\footnotetext{
${ }^{1}$ Valbuena Briones 1991: 1225.

${ }^{2}$ Id. ibid.

${ }^{3}$ Id. ibid.

${ }^{4}$ López Estrada 1954: xxxv (“Introducción”).

${ }^{5}$ Grove 1980: 3.645-646.

${ }^{6}$ Valbuena Briones 1991: 1722-1723.

${ }^{7}$ Grove 1980: 3.616.

${ }^{8}$ López Estrada 1954: xxxv (“Introducción”).
} 
Tenemos al menos tres grandes comediógrafos en España en el siglo XVII, Lope de Vega (1562-1635), Juan Pérez de Montalván (1601 o 16021638) y Pedro Calderón de la Barca (sin contar aquí a Cervantes), que conocen a Heliodoro y se ocupan de recrearlo en prosa o en piezas teatrales. Lope lo llama el "divino" ("griego poeta divino") en La dama boba y, como Cervantes, aunque con anterioridad, lo imita en su novela El peregrino en su patria, cuya primera edición es de 1604, es decir, trece años anterior a la publicación póstuma de Persiles y Sigismunda de 1617, pero de una época en que Cervantes mismo se consagraba ya a la imitación del novelista griego. Así lo hace en el Quijote (primera parte, 1605) y en sus novelas cortas que se publican como Novelas ejemplares en 1613 - algunas de esas novelas habían sido escritas antes de 1605, aunque quizás no aquellas que predominarán en el conjunto como recreaciones de las Etiópicas, La Gitanilla, que las encabeza, La ilustre fregona y La española inglesa, que se alternan con otras inspiradas en otros novelistas antiguos, Rinconete y Cortadillo", en Petronio, y el Coloquio de los perros, en Apuleyo ${ }^{10}$.

Elperegrino en supatria constituye un hito en las imitaciones de las Etiópicas en castellano. La crítica, sin embargo, ha querido ver como antecedente de ella la novela Selva de aventuras de Jerónimo de Contreras, cuyo título bien podría definir las características de la novela de amor y aventuras que se dio en llamar "novela bizantina” y de la cual el ejemplo artístico más notable y más admirado en el Renacimiento fue precisamente la novela atribuida a Heliodoro ${ }^{11}$. También creyó verse su antecedente en la Historia de los amores de Clareo y Florisea de Alonso Núñez de Reinoso, publicada en Venecia en 1552, imitación de otra novela antigua, Leucipe y Clitofonte, de Aquiles Tacio. Cabe mencionar aquí que las Etiópicas se consideraron tradicionalmente como el modelo absoluto para la producción del género en la Antigüedad y posteriormente en Bizancio y que disfrutaban en el siglo XVI de un prestigio del que ninguna de las otras novelas griegas o bizantinas llegó a gozar. Piénsese en las palabras del humanista bávaro Vinzenz Heidecker (Opsopœus) sobre los artificios de la obra: "[...] quibus nulli Græcorum authorum secundus est" - "[en los cuales] no es inferior a ningún autor griego", en la epístola dedicatoria al senado de la ciudad de

${ }^{9}$ En esa comedia, Celia, criada de Nise, dice al entregar a ésta un libro: "En cándido pergamino / vienen muchas flores de oro." Responde Nise: "Bien lo merece Eleodoro, / griego poeta divino." Sigue un comentario en verso de la obra, que recuerda el proemio de Jacques Amyot (ver infra). Citado por López Estrada 1954: xxvi.

${ }^{10}$ Salgado 1997: 272-274.

${ }^{11}$ Peyton 1971: 17. En su introducción a su edición de El peregrino en su patria, dice así, en efecto: "Varios eruditos han dado en identificar antecedentes de [esa obra] de Lope. Menéndez y Pelayo, Pfandl, Vossler y Farinelli señalan la Selva de aventuras de Jerónimo de Contreras como modelo." Farinelli ve un antecedente en Il peregrino (1508) de Jacopo Caviceo, cuya traducción castellana apareció en Sevilla en la temprana fecha de 1520. 
Nuremberg de la editio princeps de la obra en griego $(1534)^{12}$, que preparó sobre el manuscrito de la Biblioteca Corviniana (hoy en la Staatsbibliothek de Munich, Codex grecus 357). En cambio, la Selva de aventuras, historia de los desdichados amantes Luzmán y Arbolea, fue publicada recién en 1565, cuando la fama de las Etiópicas estaba ya bien extendida y establecida en Europa y contaba con traducciones al francés, al latín, al italiano y con dos al castellano, la del anónimo de Amberes (Martín Nucio, 1554) y la de Francisco de Vergara, catedrático de griego en la universidad de Alcalá de Henares, que permaneció inédita.

Si nos hemos detenido en los antecedentes de esa novela de Lope lo ha sido para mostrar que en las obras de esa época en las que no se hace mención específica de sus fuentes, éstas quedan sujetas al criterio o la erudición de los críticos modernos. No fue éste el caso ni del Persiles ni de las piezas dramáticas de Calderón y Pérez de Montalván, porque en ellas su autor o bien explícitamente dice que quiso emular a Heliodoro (Persiles) ${ }^{13}$ o bien en su propio título - Los hijos de la Fortuna: Teágenes y Cariclea - se señala el modelo con el nombre mismo de los protagonistas de la narrativa griega, con los que aparecía ya, por otra parte, en sus traducciones a lenguas romances desde la francesa de Jacques Amyot de 1547: Histoire atbiopique d'Heliodorus, contenant dix liures, traictant des loyales et pudiques amours de Theagenes Thessalien et Chariclea Athiopienne [... $]^{14}$. Similarmente, no se identificaron en las Novelas ejemplares de Cervantes unas recreaciones en miniatura de las Etiópicas, porque el novelista no lo declara así. Como en las Etiópicas mismas, su autor dejaba librado al lector erudito el reconocimiento en ellas de los pasajes, líneas de pensamiento e imágenes de las obras literarias en que se había inspirado, en su caso, Homero, los trágicos, Platón y los historiadores griegos del período clásico, Heródoto y Tucídides ${ }^{15}$. En Los hijos de la Fortuna: Teágenes y Clariquea Pérez de Montalván y Calderón hacen explícita su fuente en la narrativa de las Etiópicas de todos entonces conocida y que se había difundido en la península hispánica sobre todo con la traducción del toledano Fernando de Mena, que llevaba precisamente por título La historia de los dos leales amantes Theagenes y Chariclea, y en la cual no se mencionaba el nombre del autor - un ardid quizás para evitar la censura en las ediciones de literatura pagana después de

${ }^{12}$ Opsopœus 1534: fol. a 2 ro.: "[...] mitto uerborum ornatum \& compositionem, \& dicendi artificium, cæterasque orationis uirtutes, quibus nulli Græcorum authorum secundus est $[\ldots] . ”$

${ }^{13}$ Lo anuncia en el "Prólogo al lector" de las Novelas ejemplares. "Tras ella, si la vida no me deja, te ofrezco los Trabajos de Persiles, libro que se atreve a competir con Heliodoro, si ya por atrevido no sale con las manos en la cabeza, [...].” (Cervantes 1976: 1.88).

${ }^{14}$ Amyot 1547.

${ }^{15}$ Feuillâtre 1966; Salgado 2010: 161. 
los edictos del Concilio de Trento - (Alcalá, Juan Gracián, 1587; reimpresa en Barcelona por Gerónymo Margarit en 1614 y en Madrid, por Alonso Martín, a costa de Pedro Pablo Borgia, 1615 y en París, Pedro Le-Mur, 1616, en la edición del intérprete y gramático francés César Oudin). "El título de Teágenes y Clariquea denunciaba a las claras la procedencia del argumento”, decía López Estrada $^{16}$.

La forma dramática para la historia de los amantes Teágenes y Cariclea sólo se adoptará en España en el siglo XVII. De acuerdo con el mismo estudioso, "no cupo mayor reto a las unidades aristotélicas como el que supone esta empresa; pero aun considerando las más extremas condiciones de libertad escénica, el teatro quedaba estrecho para un tal barullo de acción y de personajes"17. Así juzgaba López Estrada: "Ninguna de las comedias inspiradas en este libro fue de gran importancia, pues era de una dificultad extraordinaria meter el inmenso enredijo de la Historia Etiópica en los límites de espacio, lugar y tiempo de un argumento de comedia"18. Como la pieza de Juan Pérez de Montalván es muy rara, sólo hemos podido ver los resúmenes de su argumento publicados independientemente por George William Bacon, entre las "Comedias heroicas" de Montalván, en 1912 ${ }^{19}$, y por Francisco López Estrada, en la introducción de su reimpresión de la traducción de Fernando de Mena (1954) ${ }^{20}$. Después de su resumen, López Estrada concluye que "en conjunto, la comedia es entretenida en lo episódico y por la belleza de algunos parlamentos. Queda a más altura la parte narrativa de acciones realizadas, que la dramática," pero que "son demasiados episodios y sucesos, y el espacio para desarrollarlos es escaso", aunque "la obra es en conjunto una comedia discreta" ${ }^{21}$. Si bien Montalván ha conservado la línea argumental de las Etiópicas, se observa una notable redistribución de roles y la creación de personajes: Nemón (Cnemón) es ahora "príncipe de la China"; Neusiclés, sacerdote de Isis, por ejemplo, en lugar de Calasiris, y entre los personajes nuevos hay que citar Anaximandro, rey de Persia, Eumenes, rey de Egipto, Sinforosa, infanta de Egipto, y muchos criados. Calderón, en cambio, se muestra más fiel al original, aunque agrega un coro de ninfas y músicos, de

${ }^{16}$ López Estrada 1954: xxxii.

${ }^{17}$ Id. ibid.

${ }^{18}$ Id. ibid.

${ }^{19}$ Bacon 1912: 120-124 (Section II, Analyses), y notas, id.: 339-340.

${ }^{20}$ López Estrada 1954: xxxii-xxxiv, tomada del Segrondo Tomo de las Comedias del Doctor Ivan Perez de Montalvan [...] En Madrid. En la Imprenta del Reyno Año 1638. [...], ff. 112vo.134vo.; lleva por título: "Teaganes, y Clariquea [sic]. Comedia famosa del doctor Ivan Perez de Montalban." Según Bacon, el título de la comedia es igual al de Calderón.: "Los hijos de la Fortuna: Teágenes y Clariquea." Aparece aquí el nombre de Cariclea con metátesis: "Clariquea", común a varios autores (cf. López Estrada 1954: xxxii n. 1).

${ }^{21}$ Id.: xxxiv. 
acuerdo, como venimos viendo, con sus fines "operísticos". Calderón es una figura bien conocida en la historia de la ópera ${ }^{22}$.

La presencia de músicos y coros puede verse en la lista de personajes de la comedia de Calderón, que es la siguiente: "Cariclés, viejo; Calasiris, viejo; Nausiclés, mercader; Tisbe, esclava; Idaspes, indio negro; Cariclea, dama india; Persina, Reina de Etiopía, india negra; un Capitán y soldados; Tíamis, bandolero y galán; Termutes, bandolero; Jebnón, bandolero gracioso; Petosiris, galán, hermano de Tíamis; Teágenes, galán; tres caminantes; Admeta, Reina de Menfis; Ninfas de Apolo, músicas; Criadas de Persina, músicas indias; negras; músicos, bandoleros y soldados" ${ }^{23}$. Calderón inicia su drama en la ciudad griega de Delfos, con la vista exterior del templo de Apolo. Entra primero un coro de Ninfas (sacerdotisas de Apolo) cantando y luego los ancianos sacerdotes Cariclés (de Apolo, y padre adoptivo de la protagonista Cariclea) y el egipcio Calasiris (de Isis). Convocan al pueblo a la ceremonia sagrada en el templo el primer solsticio de junio. En la escena que sigue, en el interior del templo vuelven a aparecer Cariclés y la tropa de músicos. Cantan dentro y salen luego "músicas indias negras" (etíopes) y Persina, india negra, reina de Etiopía. Sale Idaspes con las señales de reconocimiento de Cariclea, la banda con letras de oro y joyas en un cofrecillo (en las Etiópicas, es Cariclés quien las muestra). Fuera del templo, la salida de Cariclés y Calasiris es acompañada de chirimías, instrumentos y cajas. Salen por una parte las Ninfas con Cariclea y un hacha encendida y por otra, los Músicos, Teágenes y acompañamiento y el primer acto termina con música y canciones.

En la escena en el bosque en el segundo acto vuelven a tocar chirimías y, a orillas del Nilo, se recrea luego el cuadro de apertura de las Etiópicas: "Córrese una cortina y vése la mesa derribada y algunos como muertos, y entre ellos Cariclea y Teágenes, herido" 24 . Sigue la escena en la gruta con el asesinato de la esclava Tisbe, por error, por parte del jefe de los bandoleros Tíamis. Teágenes se lamenta pensando ser Cariclea la muerta, pero Cariclea aparece viva en el fondo de la cueva, como en la novela (Eth. 2.5.1).

$\mathrm{El}$ acto tercero transcurre en Egipto; Teágenes ha sido hecho prisionero y Cariclea, esclava de Nausiclés. En este acto "se insiste en la peripecia de la acción", como señala Valbuena Briones ${ }^{25}$. Los protagonistas "se salvan de un peligro para caer en otro" 26 . Dicen ser hermanos, "lo mismo que el poema

${ }^{22}$ Lamentablemente, no se conservó la música escrita para esta obra. El compositor de la corte era Juan Hidalgo y nos han llegado varias de sus partituras que acompañaban otras piezas de Calderón (Grove 1980: 617).

${ }^{23}$ López Estrada 1954: xxxiv n. 1.

${ }^{24}$ Valbuena Briones 1991: 1247.

${ }^{25}$ Id.: 1.224.

${ }^{26}$ Id. ibid. 
de Heliodoros, para evitar envidias y asegurar su amor sin recelos”, según el mismo editor ${ }^{27}$. En los confines de Etiopía y Egipto, aparece Persina con acompañamiento de músicos. En batalla con la reina de Egipto Admeta, los etíopes triunfan. La comedia termina con el reconocimiento de Cariclea por parte de sus padres Idaspes y Persina y su matrimonio con Teágenes, que se descubre ser también de linaje real, de Tesalia. La escena final tiene lugar con el sonido de cajas y gran acompañamiento de etíopes y gitanos. El cierre está a cargo de Jebnón (Cnemón). En las Etiópicas, este personaje representa al Hipólito de Eurípides, que ha escapado a la muerte, en exilio en Egipto. Calderón captó el carácter cómico de este personaje en la novela y lo convirtió adecuadamente en gracioso ${ }^{28}$, pero en las Etiópicas Cnemón desaparece de la acción en el libro VI, al esposar la hija del rico mercader griego Nausiclés (Ath. 6.8.1) y hallar así, en una vida sedentaria en la aldea egipcia de Quemnis, el fin de sus aventuras. Con la boda real y los festejos en la capital de Etiopía, Méroe, la novela concluía con un gran finale operístico ${ }^{29}$. En boca de Cnemón había puesto su autor ya en cita aproximada las palabras de Eurípides (Medea,1317), “¿para qué remover y forzar ese secreto, como dicen los autores trágicos?" (Ath. 1.8.7 $)^{30}$, como para recordar toda la teatralidad que imbuía a su propia obra - en Eurípides, Medea dice a Jasón: “¿Para qué agitar [el coro de mujeres] y romper esas puertas?” En una correcta lectura de las Etiópicas, Calderón encomendaba así a Jebnón las palabras finales de esta comedia. También Teágenes, que aparece como un par cómico de Cnemón en el libro I de la novela de Heliodoro, "en su dolor, lanzó rugidos trágicos" (Æth. 2.4.1).

Émile Feuillâtre, en su estudio sobre las Etiópicas, sugería que su autor, aunque no lo nombrara, se sentía más cercano de Eurípides que de Esquilo o Sófocles y proporciona como ejemplo la imagen inicial de la obra, los rayos de sol naciente que iluminan las colinas en el delta del Nilo: "[...] une même lumière éclaire le mont Ida dans les Troyennes et le Parnasse dans Ion" - nos dice - . Dans cette dernière tragédie, tout au début, nous voyons agir le néocore d'Apollon. De même, chez Héliodore, dans la lumière de l'aube apparaît la zacore d"Artémis"31. Calderón debió conocer tan bien a Eurípides como la obra de ficción en prosa que se inspira en gran parte en sus tragedias, las Etiópicas ${ }^{32}$.

${ }^{27}$ Id. ibid.

${ }^{28}$ Respecto de la comicidad de Cnemón, Feuillâtre nos recuerda que Heliodoro "[...] ne cesse de railler Cnémon, sa suffisance et sa couardise.” (Feuillâtre 1966: 118). J. Maillon anota, después de señalar que el adjetivo griego 'haploïós' ("ingenuo") es común en Luciano: "La naiveté de Cnémon introduit une note comique dans toute la premiére partie du drame." (Héliodore 1960: 1.17 n.3).

${ }^{29}$ Salgado 2010: 159.

${ }^{30}$ Grimal 1963: 528 y 1468 n. 528.1.

${ }^{31}$ Cf. Eur. Troyennes, 1066-1070; Ion, 86-88 (Feuillâtre 1966: 116-117).

32 Salgado 2004. 
Refiriéndose no a la pieza dramática que estamos tratando sino a "Las armas de la hermosura" (Parte cuarenta y seis. Primavera numerosa de muchas armonías lucientes en doce comedias fragantes, Madrid, 1679), Valbuena Briones expresaba: “[...] el autor [Calderón], en una línea de pensamiento que podríamos llamar euripidiana, buscó representar una fábula en la que la invención y la fantasía tuvieran un papel primordial"33. Sin duda, tiene presente este estudioso aquí el tratamiento del mito en Eurípides ${ }^{34}$.

Otra pieza dramática de Calderón brinda un nuevo ejemplo de interpretación de la obra de este trágico. Los tres mayores prodigios (Parte Segunda de Comedias, Madrid, 1637) es un experimento (a cargo de tres compañias teatrales diferentes, una para cada acto $)^{35}$ en el que se tratan en cada una de las tres jornadas, respectivamente, los mitos de la conquista del vellocino de oro por Jasón, la muerte del Minotauro por Teseo y los amores trágicos de Hércules y Deyanira. En la segunda jornada, “[...] la queja y maldición de Ariadna anuncian los episodios trágicos que según la mitología envolverán los amores de Teseo y Fedra", según su editor. Teseo debía "escoger entre el objeto de su amor o la correspondencia de gratitud que debe. En este conflicto se deja llevar injustamente de la pasión amorosa," de acuerdo con el mismo estudioso. Esa pasión es la que lo ciega igualmente al condenar al exilio (y a la muerte) a su hijo Hipólito, como le reprocha Ártemis (Hipp. 1586). Pérez de Montalván nos ofrece, muy a propósito, una magnífica ilustración del tema de esa tragedia en la primera de sus novelas ejemplares, La hermosa Aurora (Sucesos y prodigios de amor en ocho novelas ejemplares, Madrid, 1624): "No le disculpe esta vez a Dionisio el amor, con ser disculpa general de cualquier exceso, porque no tiene obligación un hombre a despreciar prendas, que lo son de su sangre, por una mujer que miente cuando llora y llora cuando quiere" ${ }^{36}$ En esta novela, Dionisio representa a Teseo; Arminda, su segunda esposa, dama francesa y principal, a Fedra, extranjera como ella, y Aurora, hija del primer matrimonio de Dionisio, a Hipólito. Hay que recordar que es en la versión del mito que Cnemón relata en las Etiópicas como su historia personal (Ath. 1.9.1-1.17.5), donde la madrastra Deméneta se presenta como la mujer malvada cuyas intrigas inspirarán en el siglo XVII a Racine, gran lector de Heliodoro ${ }^{37}$.

En otra pieza dramática, Calderón parece reflexionar nuevamente sobre el Hipólito de Eurípides. En Amado y aborrecido (Octava parte de comedias escogidas, Madrid, 1657, y Quinta parte de comedias de Calderón, Madrid, 1677), se presentan dos planos de acción, uno "real" y otro complementario,

\footnotetext{
${ }^{33}$ Valbuena Briones 1991: 939.

${ }^{34}$ Cf. Buttrey 1958.

${ }^{35}$ Valbuena Briones 1991: 1547.

${ }^{36}$ Laplana Gil 1999: 20.

${ }^{37}$ J. Maillon en: Héliodore 1960: 1.14 n. 2.
} 
"sobrenatural o mitológico": “[...] las diosas rivales Venus y Diana se interesan en el conflicto interior de Dante [...]. Este quehacer de los dos seres divinos viene a ser una especie de juego celestial. Los personajes semejan marionetas pulsados por las dos celosas diosas antropomorfas," según Valbuena Briones ${ }^{38}$. En Hipólito de Eurípides el argumento se desarrolla en torno de la rivalidad de esas mismas diosas, aunque el conflicto en "Amado y aborrecido" es de índole diferente.

Con una profunda comprensión tanto de esa novela antigua tan admirada en el Renacimiento como fueron las Etiópicas como de la tradición literaria en la que se inspira y que continúa ${ }^{39}$, y sin desdeñar la significación de otros géneros en su trasfondo, como la épica o la historiografía, las adaptaciones a la escena efectuadas por los dramaturgos españoles del siglo XVII devuelven en cierta forma esa novela a su prístina forma original, el drama ${ }^{40}$. La adaptación de la novela al teatro obligó por otra parte a nuestros autores a abandonar la narrativa con un principio in medias res, que había hecho célebres a las Etiópicas, a partir de un procedimiento ya utilizado en la épica: Ulises, en la Odisea, aparece sentado en una roca al comienzo del libro I, como Cariclea al principio del libro I de las Etiópicas, y el lector no sabe qué ha sucedido antes, en los nueve años que siguieron a la partida de Ulises de Troya, lo que el héroe sólo relata en los libros IX, X, XI y XII. Las circunstancias por las cuales Cariclea ha llegado a las costas del delta del Nilo se conocerán con el relato del sacerdote Calasiris en los libros II a V. Jacques Amyot, en el prefacio de su primera traducción de la obra al francés (1547), alaba particularmente esa técnica: "Y por cierto la dispo[si]ción es singular, porque comienza en la mitad de la Historia, como hacen los poetas heroicos, lo cual causa, de prima facie, una grande admiración a los lectores, y les engendra un apasionado deseo de oír y entender el comienzo, y todavía los atrae también con la ingeniosa lección de su cuento, que no entienden lo que han leído en el comienzo del primer libro, hasta que veen el final del quinto, y cuando allí han llegado, aún les queda mayor deseo de ver el fin, que antes tenían de ver principio. De suerte que siempre el entendimiento queda suspenso hasta que viene a la conclusión, la cual deja al lector satisfecho, como lo son aquellos que al fin vienen a gozar de una cosa muy deseada y de mucho tiempo esperada" ${ }^{41}$ El proemio de Amyot en

${ }^{38}$ Valbuena Briones 1991: 1681.

${ }^{39}$ Salgado 2004.

${ }^{40}$ Focio llamó a la novela antigua "drama”, como en Polibio, "acontecimiento (histórico) trágico” (Plb.13.10.12), y lo relativo a ella, “dramaticós” (Focio 1959-1991: passim).

${ }^{41}$ López Estrada 1954: 1xxx-lxxxi. El anónimo traductor de Amberes, 1554, incluyó en su versión castellana de las Etiópicas este prefacio, que es la que utilizamos aquí. López Estrada lo transcribió al final de su introducción a la reimpresión de la traducción de Fernando de Mena (López Estrada 1954: 1xxvii-lxxxiii). 
esa temprana fecha de 1547 constituyó un verdadero "tratado de la novela" de su época, que sentaría los fundamentos del género en las literaturas modernas. López Estrada afirmaba que Calderón en Los hijos de la Fortuna, Teágenes y Cariclea "[...] amontona [los episodios] sin apenas sentido de continuidad, y propende a la comedia de gran espectáculo, con artificios escénicos, cantos corales [...]" ${ }^{42}$, pero, al hacerlo, ese gran estudioso de la recepción de las Etiópicas en la literatura española no comprendió que era allí, precisamente, en el gran espectáculo, los artificios escénicos y los cantos corales, donde el dramaturgo y libretista, en esa última etapa de su producción, seguía las experiencias de la Camerata florentina del círculo del conde Giovanni de' Bardi, con las investigaciones sobre música griega de Vincenzo Galilei y su urgencia por recrear, con música, la escena antigua, como habían hecho los italianos con los dramas musicales Dafne (1598) y Euridice (1600) de Jacopo Corsi. Más que una falencia, fue un logro de Calderón desde el punto de vista de la revivificación de la tragedia clásica en el género de la ópera culta en España ${ }^{43}$.

42 Id.: xxxv.

43 A pesar de los esfuerzos de Calderón, el género operístico no prosperó en España, sino sólo como zarzuela, "[...] the more frivolous, increasingly plebeian zarzuelas of the later 17 th and 18th centuries" (Grove 1980: 3.617). 


\section{Bibliografía}

Amyot J. trad. 1547, Histoire athiopique d'Heliodorus, contenant dix liures, traictant des loyales et pudiques amours de Theagenes Thessalien et Chariclea Athiopienne : nouvellement traduite du grec en françoys, à Paris, pour Jean Longis, libraire [...]. Colofón: Imprimé à Paris par Estienne Groulleau, et fut achevé le quinziesme jour de Février 1547.

Bacon G. W. 1912, "The life and dramatic works of Doctor Juan Pérez de Montalván”, Revue Hispanique 26, 1-474.

Buttrey T. V. 1958, "Accident and design in Euripides' Medea", American Journal of Philology 79.1 (313), 1-17.

Cervantes M. de 1976, Novelas ejemplares, ed. M. Baquero Goyanes, Madrid, Editora Nacional, Biblioteca de la literatura y el pensamiento hispánicos, 2 vols.

Feuillâtre E. 1966, Études sur les Éthiopiques d'Héliodore. Contribution à la connaissance du roman grec, París, Presses Universitaires de France, Publications de la Faculté de Lettres et Sciences Humaines de Poitiers.

Focio 1959-1991, Bibliothèque, R. Henry ed. y trad., París, “Les Belles Lettres", Collection Bizantine publiée sous le patronage de la Association G. Budé, 9 vols.

Grimal P. ed.y trad. 1963, Romans grecs et latins, París, Gallimard, Bibliothéque de "La Pléyade" 134.

Grove G. 1980, The New Grove Dictionary of Music and Musicians, ed. S. Sadie, Londres, Macmillan / Washington, Grove's Dictionaries of Music Inc. / Hong Kong, Peninsula Publishers Ltd., 3.

Héliodore 1960, Les Éthiopiques (Théagène et Chariclée), R. M. Rattenbury y T. W. Lumb edd., J. Maillon trad., París, "Les Belles Lettres", Coll. des Universités de France, 3 vols.

Laplana Gil E. ed. 1999, Juan Pérez de Montalván, Obra no dramática, Madrid, Biblioteca Castro, Edics. de la Fundación José Antonio de Castro.

López Estrada F. ed. 1954, Historia etiópica de los amores de Teágenes y Cariclea traducida en romance por Fernando de Mena, Madrid, Aldus, RAE, Biblioteca de Clásicos Españoles.

Peyton M. A. ed. 1971, Lope de Vega, El peregrino en su patria, Chapel Hill, Univ. of North Carolina Press, Studies in the Romance Languages and Literatures 97 . 
Salgado O. N. 1997, "La Historia Etiópica, un precedente de La Gitanilla en la novela griega”, $A F C$ 15, 270-287.

___ 2004, "Hipólito de Eurípides en la creación de la Historia etiópica de Heliodoro", en: Ética y estética. De Grecia a la modernidad. Tercer Coloquio Internacional, 10-13 de junio de 2003, La Plata, Universidad Nacional, Facultad de Humanidades, CELC-AFG. CDRom.

2010, "Heliodoros Polyhistor: Para una reevaluación de los datos externos de la Historia Etiópica", en: Philologiae Flores. Homenaje a Amalia S. Nocito, M. E. Steinberg y P. Cavallero eds., Buenos Aires, Universidad de Buenos Aires, Facultad de Filosofía y Letras, Instituto de Filología Clásica, 147-165.

Valbuena Briones A. 1991, Don Pedro Calderón de la Barca, Obras completas. Tomo II, Dramas, nueva ed., prólogo y notas de [...], Madrid, Aguilar, $5^{\mathrm{a}} \mathrm{ed}$. 